But when Iree lysine was added to the cereal, the performances (grow th rate, feed efficiency) were significantly higher $(+\& \mathrm{p}, 100)$ than those obtained in pigs when lysine was adeled to the oil-meal.

\title{
Eifect of dietary amino acid balance (lysine deliciency) and protein level on growing pig periormances
}

\author{
Y. HENRY, 1) BOTRI) \\ itation de Richerthe's sur l'Elerage des pores, I. N.R. I., C. N.R.Z. \\ 78.3.5\% Jouy in Josas
}

Three groups of 20 animals were kept in individual pens (between $2 \mathrm{f}$ and $100 \mathrm{~kg}$ live weight) in order to study the consequences of dietary protein reduction after amino acid supplementation, on growth performances and body composition of pigs under restricted feeding conditions and according to sex.

… (iroup BJ, lysine deficient (0.6 p. 100 up to $+5 \mathrm{~kg}$ live weight and $0 .+\mathrm{p}$. Ioo beyond that weight). but with a suitable protein supply (17.2 until $45 \mathrm{~kg}$, then 19.5 ).

.... (iroup HL, receiving a lysine supplementation, the total lysine contents being $0.80-0.05$ and $0.60 \mathrm{p}$. Ioo respectively before $+5 \mathrm{~kg}$, between 45 and $70 \mathrm{~kg}$ and after $70 \mathrm{~kg}$ live weight.

- Group BSN, recoiving a reduced supply of protein ( $3.5 \mathrm{P}$. Ioo up to $45 \mathrm{~kg}$ and $\mathrm{I} 2 \mathrm{p}$. Ion) beyond that weight), but suitably supplemented with essential amino acids.

The diets were composed of a mixture of cereals (barley, wheat and maize) providing it digestible energy value of 3 Ioo $\mathrm{kcal} / \mathrm{ks}$

The favourable influence of lysine supplementation showed that the reguirement was higher in the females than in the castrated males.

likewise, a difference between sexes was noted in the response to crude proten reluction, the requirements for e'sstntial amine acids being anvhow satisfid. In the case of castrated males subjected to usual feed restriction (progressive supply up to $2.7 \mathrm{~kg} / \mathrm{day}$ at $8 \mathrm{kog} \mathrm{kive}$ weight), the total requirement for crucle protein secmed to be satisfied by the levels: I + p. roo during the growing period and $12 \mathrm{p}$. 100 during the finishing periol (over $50 \mathrm{~kg}$ ), corresponding to +5 and fo g crucle protein/I ooo kcal digestible energy. This leals to a sparing of $15-20$ p. 1 so protein as compared to the recommended standards. However, in the females subjected to a more liberal feeding level (until $2.95 \mathrm{~kg} / \mathrm{day}$ ), the supply of crude protein must be maintained at a higher level, notably cluring early growth, to prevent excessive carcass adiposity. 